\title{
The influence of A-band and B-band lipopolysaccharide on the surface characteristics and adhesion of Pseudomonas aeruginosa to surfaces
}

\author{
Stephen A. Makin and Terrance J. Beveridge \\ Author for correspondence: Stephen A. Makin. Tel: +1 5198244120 . Fax: +15198371802. \\ e-mail: SMakin@UOGuelph.ca
}

Department of Microbiology, College of Biological Sciences, University of Guelph, Guelph, Ontario, Canada N1G 2W1

\begin{abstract}
Pseudomonas aeruginosa PAO1 possesses two distinct lipopolysaccharide (LPS) O-polysaccharide species, A- and B-band LPS, the relative expression of which appears to be under environmental control. In an attempt to identify the influence these LPS types have on surface characteristics and adhesion, we examined the surface hydrophobicity and surface charge of $P$. aeruginosa PAO1 (05 serotype) and its isogenic LPS derivatives which possessed $A^{+} B^{-}, A^{-} B^{+}$ and $A^{-} B^{-}$LPS. The surface characteristics of the strains affected their ability to adhere to hydrophilic (glass) and hydrophobic (polystyrene) surfaces. Cells possessing only A-band LPS demonstrated the highest surface hydrophobicity, followed by the strain lacking both A- and B-band LPS. The presence of B-band LPS resulted in a more hydrophilic surface. Strains lacking B-band LPS ( $A^{+} B^{-}$and $\left.A^{-} B^{-}\right)$had more electronegative surfaces than those possessing B-band LPS $\left(A^{+} B^{+}\right.$and $\left.A^{-} B^{+}\right)$, with cells lacking both $A-$ and $B$-band LPS showing the highest surface electronegativity. These data suggest that the main surface-chargedetermining groups reside in the core region of the LPS molecule. Cells with the lowest surface hydrophobicity and lowest surface charge $\left(A^{+} B^{+}, A^{-} B^{+}\right)$ adhered to glass the most efficiently, implying a role for electrostatic interaction, whereas adhesion to polystyrene mirrored the relative hydrophobicities of the strains $\left(A^{+} B^{-}>A^{-} B^{-}>A^{+} B^{+}>A^{-} B^{+}\right)$. It is postulated that phenotypic variation in the relative expression of $A-$ and $B$-band LPS may be a mechanism by which $P$. aeruginosa can alter its overall surface characteristics in such a way as to influence adhesion and favour survival.
\end{abstract}

Keywords: Pseudomonas aeruginosa, adhesion, biofilms, surface hydrophobicity, surface charge

\section{INTRODUCTION}

Bacterial adhesion to solid substrata has been demonstrated in numerous environments and is one of the initial steps in the formation of biofilms, which occur on virtually any surface exposed to bacterial populations (Costerton et al., 1987). These include such diverse settings as industrial (Christensen \& Characklis, 1990) and natural ecosystems (Dazzo, 1984; Lock, 1993), pipelines, and water distribution systems (Herson et al., 1987). In addition, Pseudomonas aeruginosa is an important opportunistic human pathogen and is often found to be

Abbreviation: HIC, hydrophobic interaction chromatography. the causative organism in device-associated infections involving urinary catheters (Nickel et al., 1985; Warren, 1987), contact lenses (Miller \& Ahearn, 1987; Ormerod \& Smith, 1986) and prosthetic joints (Brause, 1989). It has been recognized that the physiology of cells growing within established biofilms varies significantly from that of their planktonic counterparts (Davies \& Geesey, 1995; Giwercman et al., 1991; Kinniment \& Wimpenny, 1992). Only recently, however, has it become evident that attachment to a surface can prompt changes in the expression of certain genes (Dagostino et al., 1991 ; Davies et al., 1993), although whether these changes are prompted by attachment per se or by indirect surface effects (e.g. pH changes, accumulation of degradation products at the surface) remains to be investigated. Non-specific surface 
characteristics such as hydrophobicity and surface charge can profoundly influence the initial interactions with such surfaces (Gilbert et al., 1991; Gordon \& Millero, 1984; Stenstrom, 1989; Van Loosdrecht et al., 1987a, b), as well as with eukaryotic cells (Kihlstrom \& Magnusson, 1980; Walan \& Kihlstrom, 1988), phagocytes (Absolom, 1988; Svanborg-Eden et al., 1987) and proteins (Absolom, 1988).

The O-polysaccharide chain of LPS has been found to be an important determinant of non-specific surface properties, and many studies have demonstrated that loss of the O-polysaccharide chain can dramatically alter the overall surface charge and hydrophobic character of the Gramnegative cell surface (Williams et al., 1986; Magnusson \& Johansson, 1977; Palomar et al., 1995). Most P. aeruginosa strains possess two chemically and immunologically distinct types of LPS, termed the A- and B-bands (Lam et al., 1989; Rivera \& McGroarty, 1989). The high molecular mass B-band defines the serotype of the strain, with the PAO1 (O5 serotype) subunit comprising two uronic acid derivatives and one $N$-acetylfucosamine residue (Knirel et al., 1988). A-band contains shorter chains composed primarily of a polymer of $\alpha 1 \rightarrow 2-, \alpha 1 \rightarrow 3-, \alpha 1$ $\rightarrow 3$-linked D-rhamnose and low levels of 2-keto-3deoxyoctonic acid (3-deoxy-D-manno-2-octulosonic acid) (Arsenault et al., 1991). It has been demonstrated that under certain growth conditions (e.g. in vivo in the cystic fibrotic lung), wild-type $P$. aeruginosa LPS undergoes phenotypic alterations such that the B-band LPS becomes entirely replaced with A-band LPS (Lam et al., 1989; Hancock et al., 1983). At present, the conditions necessary for this change are unknown.

The use of chemical mutagenesis and LPS-specific phages has generated isogenic $P$. aeruginosa strains in which the $\mathrm{A}^{+} \mathrm{B}^{+}$phenotype has been altered to $\mathrm{A}^{+} \mathrm{B}^{-}, \mathrm{A}^{-} \mathrm{B}^{+}$and $\mathrm{A}^{-} \mathrm{B}^{-}$attributes (Lightfoot \& Lam, 1991). In the present study, we have utilized these mutants to investigate the contribution of A- and B-band LPS to the overall surface character of the cell, and to determine the influence these characteristics have on adhesion to both hydrophilic and hydrophobic surfaces.

\section{METHODS}

Bacterial strains and maintenance. The $P$. aeruginosa strains used were PAO1 (H103) (wild-type: O5 B-band, A-band LPS; Hancock \& Crey, 1979), AK1401 ( $\mathrm{A}^{+} \mathrm{B}^{-}$; Berry \& Kropinski, 1986), dps89 ( $\mathrm{A}^{-} \mathrm{B}^{+}$; Kadurugamuwa et al., 1993) and $\mathrm{rd} 7513$ $\left(\mathrm{A}^{-} \mathrm{B}^{-}\right.$; Lightfoot \& Lam, 1991). A chemically defined medium (CDM) was used for routine culture and consisted of $50 \mathrm{mM}$ MOPS, $1.2 \mathrm{mM} \mathrm{K} \mathrm{K}_{2} \mathrm{HPO}_{4}, 3.2 \mathrm{mM} \mathrm{MgSO} .7 \mathrm{H}_{2} \mathrm{O}, 12 \mathrm{mM}$ $\left(\mathrm{NH}_{4}\right)_{2} \mathrm{SO}_{4}, 3 \mathrm{mM} \mathrm{NaCl}, 3 \mathrm{mM} \mathrm{KCl}, 3 \cdot 2 \mathrm{mM} \mathrm{FeSO}$. $7 \mathrm{H}_{2} \mathrm{O}$ and $10 \mathrm{mM}$ glucose. The medium was supplemented with $1 \%(\mathrm{w} / \mathrm{v})$ Casamino acids (vitamin-free), which were filter-sterilized and added to the autoclaved CDM. All bacterial strains were grown at $37^{\circ} \mathrm{C}$ with vigorous shaking (200 r.p.m.) and harvested at mid-exponential phase $\left(\mathrm{OD}_{470}=0.6\right)$. All experiments were performed at room temperature (approximately $20^{\circ} \mathrm{C}$ ).

Determination of relative surface hydrophobicity. Relative surface hydrophobicity was determined using hydrophobic interaction chromatography (HIC) as first described by Smyth $e t$ al. (1978). Octyl Sepharose CL-4B was used as the hydrophobic substrate with Sepharose CL-4B as control. Small columns $(1 \mathrm{ml}$ bed vol.) were constructed in the barrels of small transfer pipettes and held in place using a small circle $(6 \mathrm{~mm}$ diameter $)$ of Whatman no. 4 filter paper. The columns were rinsed with $3 \times 2 \mathrm{ml}$ sterile nanopure water followed by $5 \times 2 \mathrm{ml}$ of the appropriate saline solution (i.e. $0,1,2,3$ or $4 \mathrm{M} \mathrm{NaCl}$ buffered with $10 \mathrm{mM}$ phosphate buffer, $\mathrm{pH} 7 \cdot 4)$. All solutions had been previously passed through a $0.45 \mu \mathrm{m}$ membrane filter. Midexponential-phase cells $\left(50 \mathrm{ml} ; \mathrm{OD}_{470}=0 \cdot 6\right.$, approximately $4 \times 10^{8}$ c.f.u. $\left.\mathrm{ml}^{-1}\right)$ were harvested $(20000 \mathrm{~g}, 10 \mathrm{~min})$, washed in $0 \cdot 1 \mathrm{M}$ phosphate buffer $\left(\mathrm{K}_{2} \mathrm{HPO}_{4}: \mathrm{KH}_{2} \mathrm{PO}_{4}\right.$, pH 7.4), recentrifuged and resuspended in $2 \mathrm{ml}$ of the appropriate saline solution buffered with $10 \mathrm{mM}$ phosphate buffer ( $\mathrm{pH} 7 \cdot 4$ ). Aliquots $(0 \cdot 1 \mathrm{ml})$ of the cell suspension were added to the top of the columns and allowed to equilibrate for $15 \mathrm{~min}$. The columns were then rinsed with $5 \times 2 \mathrm{ml}$ of the appropriate saline solution. The turbidities $\left(\mathrm{OD}_{470}\right)$ of the eluates from the hydrophobic and control columns were determined and hydrophobicities were expressed as the percentage retention to the Octyl Sepharose column relative to the control column (Sepharose CL-4B). It should be noted that no significant binding of cells to the control columns was found for any of the strains studied (data not presented).

Determination of relative surface charge. Relative surface charge was assayed using DEAE-Sepharose CL-6B, an anionexchange resin, with Sepharose CL-6B as control. Previous studies have utilized anion-exchange resins to determine relative surface charge (Pendersen, 1981); however these methods did not utilize a control and did not, therefore, correct for nonspecific trapping within the assay column. In the present study, binding to the positively charged beads, relative to identical beads lacking the charged ligand, was determined and thus gave a reliable measure of relative surface charge.

Before construction of the columns the DEAE-Sepharose beads were mixed with control beads in a ratio of 2:3 (DEAE beads to control beads) as previous experiments had shown that this led to increased sensitivity (data not presented). Columns were constructed and prepared as for HIC columns, as were cell suspensions. The eluting medium used was phosphate buffer $(\mathrm{pH} 7 \cdot 4,0-0 \cdot 2 \mathrm{M})$. Aliquots $(0 \cdot 1 \mathrm{ml})$ of the cell suspensions were added to the columns and allowed to equilibrate for $15 \mathrm{~min}$. The columns were rinsed with $5 \times 2 \mathrm{ml}$ of the appropriate phosphate buffer and the turbidity $\left(\mathrm{OD}_{470}\right)$ of the eluates was determined. The retention to the positively charged DEAE resin relative to the Sepharose CL-6B column was calculated and expressed as percentage of cells retained. Again, no significant retention of cells to the control columns was found (data not presented).

Light microscopy of cells bound to DEAE-Sepharose beads. DEAE-Sepharose columns with cells attached were disassembled and the beads rinsed with $10 \mathrm{mM}$ phosphate buffer ( $\mathrm{pH} \mathrm{7.4).} \mathrm{Cells} \mathrm{were} \mathrm{fixed} \mathrm{in} 2.5 \%(\mathrm{v} / \mathrm{v})$ glutaraldehyde (buffered with $10 \mathrm{mM}$ phosphate buffer, $\mathrm{pH} \mathrm{7.4)}$ ) for $30 \mathrm{~min}$ at room temperature, rinsed twice with phosphate buffer, and post-fixed with $1 \%(\mathrm{w} / \mathrm{v})$ osmium tetroxide (buffered with $10 \mathrm{mM}$ phosphate buffer, $\mathrm{pH} \mathrm{7.4)}$ ) for $30 \mathrm{~min}$ at room temperature. The beads (with bound cells) were enrobed in Noble agar, dehydrated in a graded ethanol series, and embedded in LR White resin (Marivac). Ultrathin sections were prepared using a Sorvall MT1 microtome and stained with $1 \%(\mathrm{w} / \mathrm{v})$ toluidine blue. Sections were examined and photographed with a Zeiss light microscope.

\section{Adhesion assays}

Adhesion to glass. Cell suspensions were prepared as for $\mathrm{HIC}$ and resuspended in a final volume of $2 \mathrm{ml} 0.1 \mathrm{M}$ phosphate buffer $(\mathrm{pH} 7 \cdot 4)$. Sufficient suspension was added to $100 \mathrm{ml} 0 \cdot 1 \mathrm{M}$ 
phosphate buffer ( $\mathrm{pH} 7 \cdot 4$, previously passed through a $0.45 \mu \mathrm{m}$ filter membrane) such that the final cell suspension had an $\mathrm{OD}_{470}$ of 0.75 (approximately $5 \times 10^{8}$ c.f.u. $\mathrm{ml}^{-1}$ ).

Circular glass coverslips (10 $\mathrm{mm}$ diameter, Chance Propper) were soaked in concentrated nitric acid to remove any adsorbed contaminants and then rinsed five times in sterile nanopure water. The coverslips were carefully placed onto a stage made from an embedding mould with small incisions made in it, such that the coverslips were held vertically in a radial arrangement with little decrease in the surface available for bacterial adhesion. Eight coverslips were used for each strain in each experiment. The adhesion stage, with coverslips, was immersed in the cell suspension and the whole system was incubated at $37^{\circ} \mathrm{C}$ and gently shaken (30 r.p.m.). At regular intervals, the glass coverslips were carefully removed using fine sterile forceps and placed directly into a vial containing $5 \mathrm{ml}$ sterile $0.1 \mathrm{M}$ phosphate buffer ( $\mathrm{pH} 7 \cdot 4$ ) and $1 \mathrm{~g}$ previously washed and sterilized glass beads (diameter $<106 \mu \mathrm{m}$ ). The coverslips were vortexed at top speed on a Vortex Genie II mixer (Fisher Scientific) for $1 \mathrm{~min}$ to remove attached cells. Vortexing with glass beads for this time had previously been shown to remove all attached cells, but had no effect on cell viability (data not presented). Viable counts were then conducted (in quadruplicate) to determine the number of cells initially adhering.

Adhesion to hydrophobic polystyrene. Cell suspensions were prepared as for the glass adhesion assay. Whenever possible, adhesion to glass and to polystyrene was determined using cells derived from the same culture. To $50 \mathrm{ml}$ cell suspension (approximately $5 \times 10^{8}$ c.f.u. $\mathrm{ml}^{-1}$ ) was added $0.5 \mathrm{~g}$ hydrophobic polystyrene SM-2 Biobeads (Bio-Rad, mean size 75-150 $\mu \mathrm{m}$ ) which had been previously washed and sterilized. An identical suspension, without Biobeads, served as a control. At regular time intervals, $1 \mathrm{ml}$ aliquots of the suspensions were removed and passed through a small circle $(6 \mathrm{~mm}$ diameter) of Whatman no. 4 filter paper held in a $3 \mathrm{ml}$ syringe barrel to remove the Biobeads. Viable counts were conducted on the cell suspensions at various time intervals. From the drop in the cell number, relative to the control, it was possible to calculate the number of cells adhering to the beads.

Preparation of LPS. LPS was prepared by the proteinase $\mathrm{K}$ method described by Hitchcock \& Brown (1983).

SDSPAGE analysis and staining. The various LPS samples were analysed by SDS-PAGE using $12 \%(\mathrm{w} / \mathrm{v})$ acrylamide gels (Lugtenberg et al., 1975). Silver staining of the separated LPS bands was according to the method of Tsai \& Frasch (1982).

Western immunoblotting. LPS samples were transferred from SDS-polyacrylamide gels to nitrocellulose and reacted with monoclonal antibody (mAb) MF 15-4 (specific for B-band serotype O5 LPS) or mAb N1F10 (specific for A-band polysaccharide). Bands were visualized using goat anti-mouse antibodies conjugated to horseradish peroxidase which was developed using 4-chloro-1-naphthol.

\section{RESULTS}

\section{SDSPAGE banding patterns and immunoreactivities of LPS samples}

LPS samples from the $P$. aeruginosa strains were separated by SDS-PAGE and silver-stained to visualize the banding patterns (Fig. 1a). A characteristic ladder pattern can be seen for wild-type PAO1, with irregularities in the spacings and intensities of the bands. Immunoblotting of the PAO1 $\left(\mathrm{A}^{+} \mathrm{B}^{+}\right)$LPS with both A-band-specific and Bband-specific $\mathrm{mAbs}$ showed co-expression of the A-band and B-band LPS (Fig. 1b, c). The banding pattern of the B-band LPS can be clearly seen at lower molecular masses; however at higher molecular mass values the bands are poorly resolved and reacted more as a smear. Aband units can be seen in a different position in the gels, with the spacing and intensity of the ladder pattern being much more regular than that of B-band LPS, confirming the results of earlier studies (Lightfoot \& Lam, 1991; Rivera et al., 1988). The silver-stained LPS profile for strain AK1401 $\left(\mathrm{A}^{+} \mathrm{B}^{-}\right)$also showed the ladder-like bands but these were not as extensive as those for PAO1 $\left(\mathrm{A}^{+} \mathrm{B}^{+}\right)$, indicating that the bands were of lower molecular mass than B-band LPS.

Immunoblots of LPS from strain dps $89\left(\mathrm{~A}^{-} \mathrm{B}^{+}\right)$indicated that the high molecular mass material was B-band LPS and confirmed that A-band was not present. Conversely, the immunoblot of LPS derived from AK1401 confirmed the presence of A-band LPS only, without the expression of B-band LPS. Silver-stained LPS from $\operatorname{rd} 7513\left(\mathrm{~A}^{-} \mathrm{B}^{-}\right)$ lacked the ladder pattern and did not react with either $A$ band- or B-band-specific mAbs, confirming the absence of $\mathrm{A}$ - and B-band LPS.

\section{Relative surface hydrophobicity of $P$. aeruginosa and its LPS derivatives}

The hydrophobicity of the cell surface of $P$. aeruginosa strains was investigated using HIC, at a range of ionic strengths, and the results are presented in Fig. 2. A similar pattern was seen at all salt concentrations above $1 \mathrm{M}$ $\mathrm{NaCl}$, with the strain possessing only A-band LPS (AK1401) having the most hydrophobic surface (effectively $100 \%$ retention), followed by the 'rough' mutant $\left(\operatorname{rd} 7513, \mathrm{~A}^{-} \mathrm{B}^{-}\right)$. Both strains possessing B-band LPS (PAO1, $\mathrm{A}^{+} \mathrm{B}^{+} ; \mathrm{dps} 89, \mathrm{~A}^{-} \mathrm{B}^{+}$) had hydrophilic surfaces. At all ionic strengths $\geqslant 1 \mathrm{M} \mathrm{NaCl}$, the strain possessing just B-band LPS (dps89) was the most hydrophilic. The fact that the wild-type organism $\left(\mathrm{PAO} 1, \mathrm{~A}^{+} \mathrm{B}^{+}\right)$had a mean surface hydrophobicity between $A K 1401\left(\mathrm{~A}^{+} \mathrm{B}^{-}\right)$and dps89 $\left(\mathrm{A}^{-} \mathrm{B}^{+}\right)$would suggest that the overall hydrophobicity is a balance between the strongly hydrophobic nature of A-band LPS and the hydrophilic nature of Bband LPS. When a 'salting out' agent $\left[2 \mathrm{M}\left(\mathrm{NH}_{4}\right)_{2} \mathrm{SO}_{4}\right]$ was used as the eluting medium, the percentage retention to the Octyl Sepharose was accordingly higher, but the previous order was maintained (i.e. $\mathrm{A}^{+} \mathrm{B}^{-}>\mathrm{A}^{-} \mathrm{B}^{-}>$ $\mathrm{A}^{+} \mathrm{B}^{+}>\mathrm{A}^{-} \mathrm{B}^{+}$, data not presented).

When HIC is employed to study surface hydrophobicity of relatively hydrophilic organisms, high salt concentrations are used in an attempt to 'cloak' charged groups on the cell surface and maximize hydrophobic interactions. Thus, the increased binding of cells to the hydrophobic column when $10 \mathrm{mM}$ phosphate buffer alone was used was unexpected.

\section{Surface charge characteristics of $\boldsymbol{P}$. aeruginosa and its LPS derivatives}

The relative surface charge of $P$. aeruginosa and its LPS derivatives was investigated using a modification of 
(a)

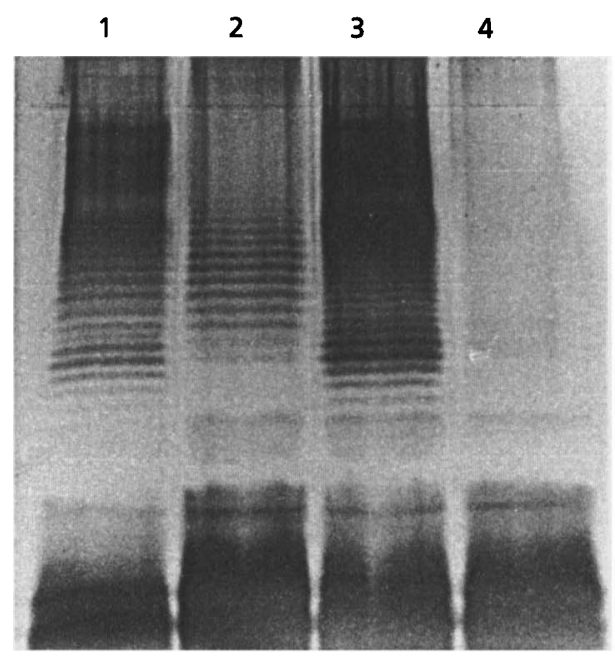

(b)



(c)

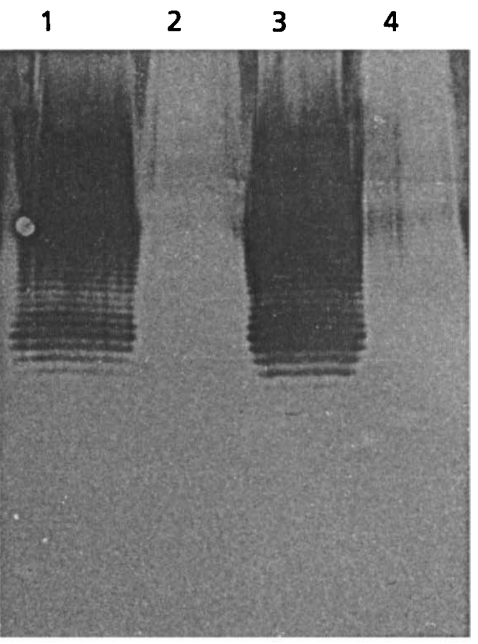

Fig. 1. (a) Silver-stained SDS-polyacrylamide gel of LPS from $P$. aeruginosa PAO1 $\left(A^{+} B^{+}\right)$(lane 1), $A K 1401\left(A^{+} B^{-}\right)($lane 2$)$, dps89 $\left(A^{-} B^{+}\right)$(lane 3$)$ and $\operatorname{rd7513}\left(A^{-} B^{-}\right)$(lane 4). Western immunoblots of these LPS profiles were reacted with A-bandspecific $\mathrm{mAb}(\mathrm{b})$ and $B$-band-specific $\mathrm{mAb}(\mathrm{C})$.

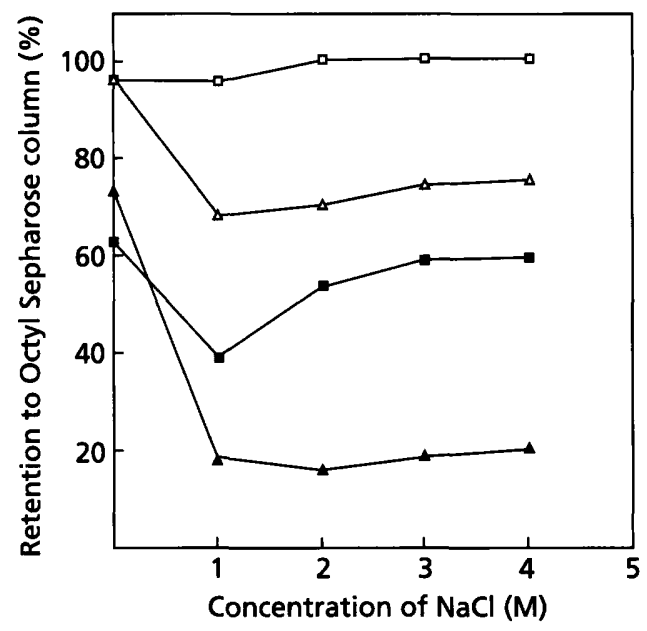

Fig. 2. Relative cell surface hydrophobicities of $P$. aeruginosa PAO1 $\left(A^{+} B^{+}\right)(\square)$ and its LPS derivatives AK1401 $\left(A^{+} B^{-}\right)(\square)$, dps89 $\left(A^{-} B^{+}\right)(A)$ and $\mathrm{rd7513}\left(\mathrm{A}^{-} \mathrm{B}^{-}\right)(\triangle)$ as determined by HIC. Relative hydrophobicities are expressed as the percentage of cells retained on the hydrophobic Octyl Sepharose column relative to a control Sepharose CL-4B column. The experiment was performed three times and a representative result is shown.

electrostatic interaction chromatography. The binding of cells to a positively charged ligand (DEAE-Sepharose CL-6B) relative to Sepharose CL-6B, at a range of ionic strengths, is presented in Fig. 3.

At low ionic strengths ( $<50 \mathrm{mM}$ phosphate buffer) there was effectively $100 \%$ retention of all strains to the charged columns. As the ionic strength of the eluting medium increased, however, there was a gradual decrease in the percentage of cells retained, due to the competition

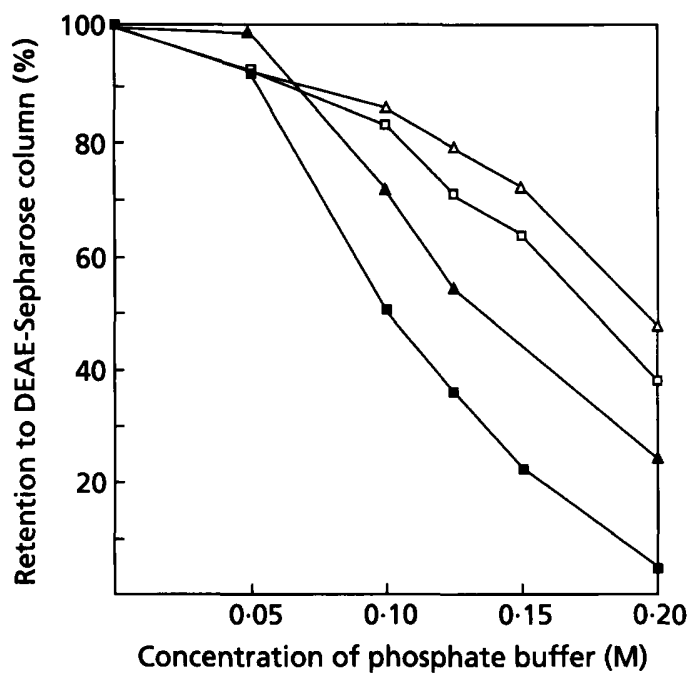

Fig. 3. Relative cell surface charge of $P$. aeruginosa $P A O 1\left(A^{+} B^{+}\right)$ (G) and its LPS derivatives AK1401 $\left(A^{+} B^{-}\right)(\square), \operatorname{dps} 89\left(A^{-} B^{+}\right)(A)$ and $\operatorname{rd7513}\left(A^{-} B^{-}\right)(\triangle)$ as determined by electrostatic interaction chromatography. Relative surface charges are expressed as the percentage of cells retained on a positively charged DEAE-Sepharose column relative to a control Sepharose CL-6B column, at a range of ionic strengths. The higher the retention values, the higher the cell surface electronegativity. The experiment was performed three times and a representative result is shown.

between anion groups on the cell surface and those present in the eluting medium (phosphate). The decrease was, however, dependent upon the LPS composition. PAO1 cells $\left(\mathrm{A}^{+} \mathrm{B}^{+}\right)$were eluted most readily from the charged column, followed by the strain possessing only Bband LPS (dps89, $\mathrm{A}^{-} \mathrm{B}^{+}$). Both strains lacking B-band LPS ( $\left(\mathrm{rd} 7513, \mathrm{~A}^{-} \mathrm{B}^{-}\right.$; AK1401, $\left.\mathrm{A}^{+} \mathrm{B}^{-}\right)$were retained to the 


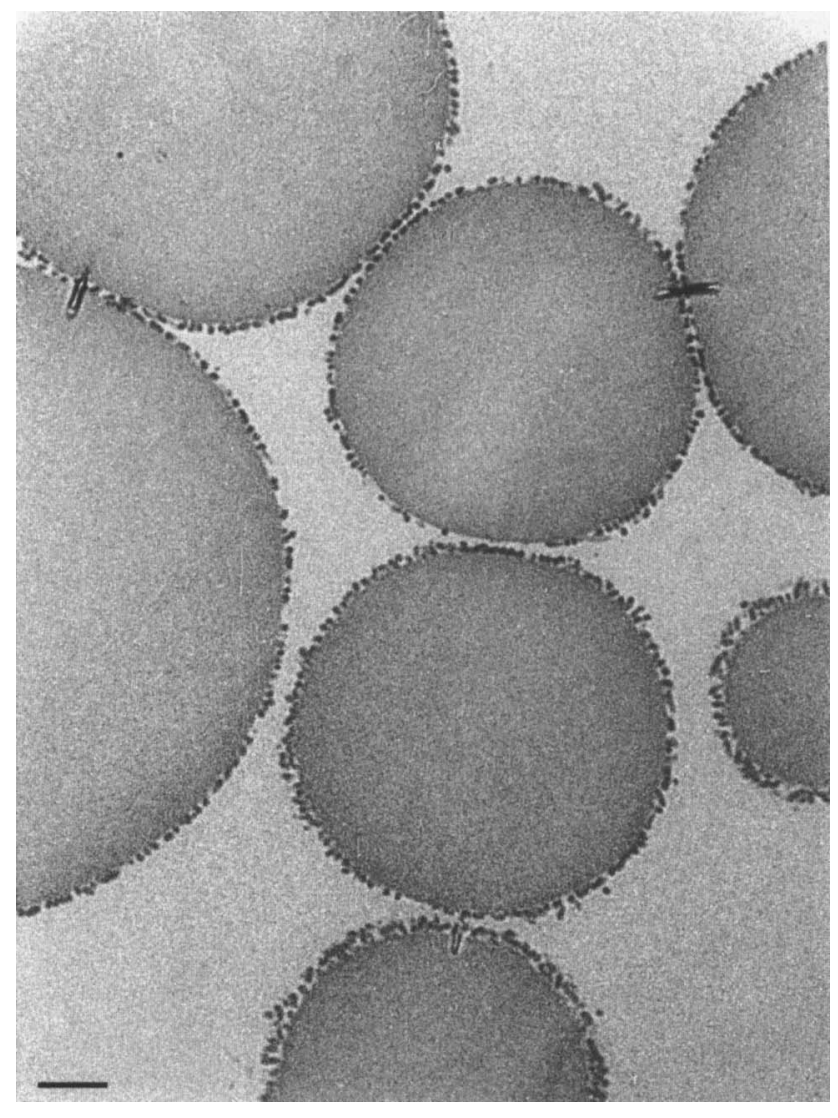

Fig. 4. $P$. aeruginosa $\mathrm{dd} 7513\left(\mathrm{~A}^{-} \mathrm{B}^{-}\right)$attached to the surface of positively charged DEAE-Sepharose beads. Beads with attached cells were fixed, dehydrated, embedded in resin and sectioned. Sections were stained with toluidine blue and examined using light microscopy. Cells can be seen to form uniform layers on the surface of the beads. Bar, $10 \mu \mathrm{m}$.

greatest extent. The fact that there is competition for the charged groups on the beads would suggest that the number of anionogenic groups exposed per unit surface area is greatest for the strain lacking both A- and B-band LPS (rd7513, $\mathrm{A}^{-} \mathrm{B}^{-}$), and lowest for the wild-type strain $\left(\mathrm{PAO} 1, \mathrm{~A}^{+} \mathrm{B}^{+}\right)$. At a phosphate buffer concentration of $0 \cdot 2 \mathrm{M}$, only $4 \cdot 2 \%$ of PAO1 cells were retained by the column, compared to $46.8 \%$ of the 'rough' mutant $\left(\operatorname{rd} 7513, \mathrm{~A}^{-} \mathrm{B}^{-}\right)$.

Since the most hydrophobic strains (rd7513, $\mathrm{A}^{-} \mathrm{B}^{-}$; $A K 1401, A^{+} B^{-}$) bound to the charged column the most effectively, co-operative binding could be responsible (i.e. multiple layers of cells binding due to hydrophobic cell-cell interactions). To investigate this hypothesis, beads with cells attached were fixed, dehydrated, embedded in resin and sectioned. The sections were stained with toluidine blue and examined under the light microscope. Fig. 4 shows beads which have been 'saturated' with cells by loading approximately 10 times the number of cells routinely loaded, and is representative of all four strains. Binding of cells was primarily as a monolayer with almost complete coverage of the bead surface. No co-

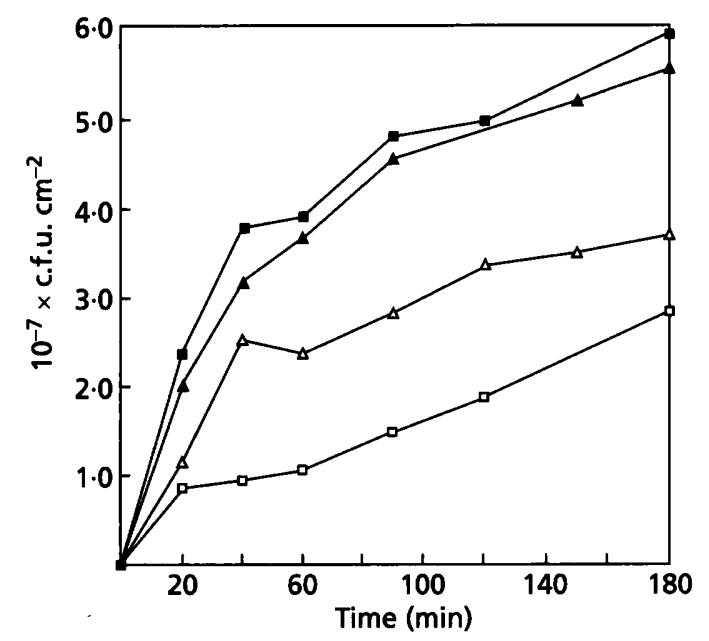

Fig. 5. Adhesion to glass of $P$. aeruginosa PAO1 $\left(A^{+} B^{+}\right)(\square)$ and its LPS derivatives AK1401 $\left(A^{+} B^{-}\right)(\square)$, dps89 $\left(A^{-} B^{+}\right)(A)$ and rd7513 $\left(A^{-} B^{-}\right)(\triangle)$. Cleaned glass coverslips were placed in washed cell suspensions (approximately $5 \times 10^{8}$ c.f.u. $\mathrm{ml}^{-1}$ ) and incubated at $37^{\circ} \mathrm{C}$. At regular intervals, coverslips were removed and the number of cells adhering was determined by vortexing with glass beads and viable counting. The experiment was performed three times and a representative result is shown.

operative binding was seen, even for the most hydrophobic strains. These results indicate that the extent of binding to the positively charged beads is mediated primarily by charge-charge interactions.

\section{Adhesion to glass}

The adhesion of PAO1 and its LPS derivatives to glass was determined using nitric-acid-cleaned glass coverslips as a substratum. The number of cells adhering was determined by removal of attached cells and viable counting. Results are presented in Fig. 5. Adhesion to glass was rapid for all strains (up to $2.4 \times 10^{7}$ c.f.u. $\mathrm{cm}^{-2}$ in $20 \mathrm{~min}$ ). The extent of adhesion was, however, dependent upon the LPS composition of the cell surface. Strains possessing B-band LPS (PAO1, $\mathrm{A}^{+} \mathrm{B}^{+}$; dps89, $\mathrm{A}^{-} \mathrm{B}^{+}$) adhered to the greatest extent; after $180 \mathrm{~min}$, in strains possessing B-band LPS, the numbers adhering were approximately double when compared to those lacking Bband LPS (AK1401 and rd7513). The presence or absence of A-band LPS seemed to have little influence on the tendency to adhere. The fact that there was no significant difference between PAO1 $\left(\mathrm{A}^{+} \mathrm{B}^{+}\right)$and $\operatorname{dps} 89\left(\mathrm{~A}^{-} \mathrm{B}^{+}\right)$ would again suggest that the presence of $B$-band LPS was the main mediator of adhesion to glass.

\section{Adhesion to polystyrene}

The adhesion of cells to hydrophobic polystyrene occurred extremely rapidly (Fig. 6). The number of cells attached to the Biobeads rose sharply in the first $10 \mathrm{~min}$ and reached a plateau value within $20 \mathrm{~min}$. The extent of adhesion was, again, highly dependent upon the LPS 


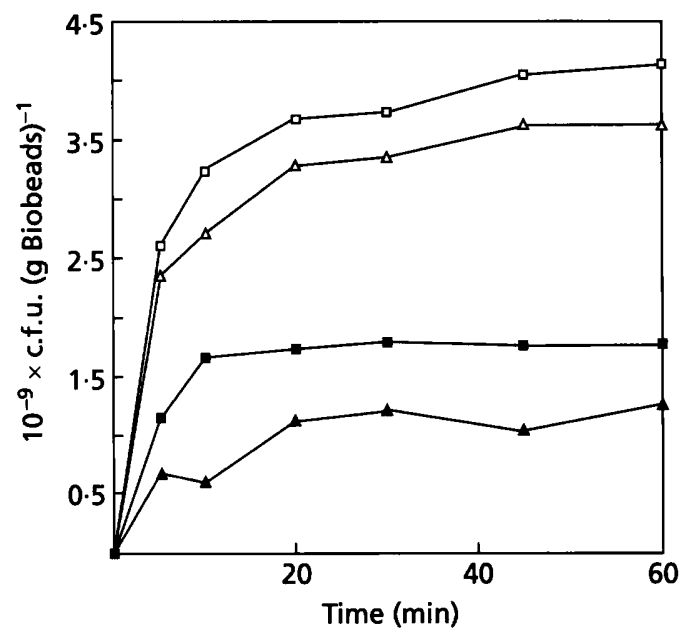

Fig. 6. Adhesion to polystyrene of $P$. aeruginosa PAO1 $\left(A^{+} B^{+}\right)$ (D) and its LPS derivatives AK1401 $\left(A^{+} B^{-}\right)(\square)$, dps89 $\left(A^{-} B^{+}\right)(A)$ and $\mathrm{rd7513}\left(\mathrm{A}^{-} \mathrm{B}^{-}\right)(\triangle)$. Washed cell suspensions (approximately $5 \times 10^{8}$ c.f.u. $\left.\mathrm{ml}^{-1}\right)$ were incubated $\left(37^{\circ} \mathrm{C}\right)$ with hydrophobic SM2 Biobeads. At regular intervals, $1 \mathrm{ml}$ aliquots of the suspension were taken and the Biobeads were removed by filtration. The number of cells attaching was calculated from viable counting of suspended cells, relative to a suspension without Biobeads. The experiment was performed three times and a representative result is shown.

composition of the cell surface; the greatest adhesion was seen for the strain possessing A-band LPS only (AK1401) followed by the 'rough' mutant lacking both $A$ - and Bband LPS. Strains possessing B-band LPS (PAO1, $A^{+} B^{+}$; dps $\left.89, \mathrm{~A}^{-} \mathrm{B}^{+}\right)$adhered less well. It is interesting to note that phenotypic removal of B-band LPS from wild-type cells resulted in adhesion to polystyrene increasing by almost $240 \%$.

The adhesion to polystyrene exactly mirrored the hydrophobicity data (i.e. $A^{+} B^{-}>A^{-} B^{-}>A^{+} B^{+}>A^{+} B^{-}$) and strongly suggested that the cell surface hydrophobicity per se determines the extent of adhesion to a hydrophobic substratum.

\section{DISCUSSION}

In the present study, major differences were found between the physicochemical characteristics of $P$. aeruginosa $\mathrm{A}-$ and $\mathrm{B}-\mathrm{band}$ LPS. The parent PAO1 strain $\left(\mathrm{A}^{+} \mathrm{B}^{+}\right)$was hydrophilic when compared to the 'rough' mutant lacking both A- and B-band LPS (rd7513). This is presumably due to the exposure of hydrophobic substituents of outer-membrane components such as phospholipids and proteins, and is supported by previous studies which have shown that variations in the $\mathrm{O}$-antigen chain length, and complete loss of the O-antigen, can profoundly affect the cell surface hydrophobicity of Gramnegative bacteria (Hermansson et al., 1982; Palomar et al., 1995; Williams et al., 1986) (it should be noted that no significant differences were found between the outermembrane protein profiles of the strains used; data not presented). The finding that possession of A-band LPS alone resulted in a more hydrophobic surface than cells lacking any O-polysaccharide chains would appear to be in contrast to previous studies. In $P$. aeruginosa PAO1, however, A-band LPS has been found to consist of short chains of predominantly neutral polysaccharides ( $D$ rhamnose, and lesser amounts of 3-O-methyl-rhamnose, ribose, glucose and mannose; Arsenault et al., 1991). Thus, a relatively hydrophobic LPS O-polysaccharide chain may shield charged groups closer to the outer membrane (2-keto-3-deoxyoctonic acid, phosphate and sulphate) and result in a higher overall hydrophobicity.

The presence of B-band LPS was found to result in a low surface hydrophobicity. B-band LPS has been found to contain an unusually high number of phosphate groups (approximately 12 per molecule) and amino sugars (Wilkinson, 1983), in contrast to A-band LPS which is effectively lacking in phosphate groups (but does contain lesser amounts of sulphate; Rivera \& McGroarty, 1989). Indeed, results from our laboratory have demonstrated that the outer membrane of strains with only A-band LPS do not easily stain with electron-dense uranyl ions $\left(\mathrm{UO}_{2}^{2+}\right)$ during the preparation of specimens for electron microscopy, whereas strains that possess B-band LPS stain darkly because of their abundant electronegative sites (Lam et al., 1992). Although the high phosphate content of B-band LPS would explain why this LPS was highly hydrophilic in nature, it would seem to conflict with the data obtained using electrostatic interaction chromatography in which both strains possessing B-band LPS were retained least by the positively charged resin. Cells lacking B-band LPS demonstrated the highest surface electronegativity, with the rough mutant ( $\left.\mathrm{rd}^{2} 513, \mathrm{~A}^{-} \mathrm{B}^{-}\right)$ possessing the most highly electronegative surface. [It should be noted that, although the combination of a high surface potential and a hydrophobic surface (i.e. $\operatorname{rd7513}$ ) would seem to be contradictory, the charged groups occupy only a minor fraction of the total surface area of the exterior outer-membrane face (approximately $8 \%$, Van Loosdrecht et al., 1987b).]

One explanation for the observed charge characteristics is that the main surface-charge-determining substituents reside in the core/lipid A region of the LPS, which is especially high in phosphate (Peterson et al., 1985). The O-side-chain of B-band LPS has been found to be significantly longer than that for A-band LPS (Rivera \& McGroarty, 1989) and electron microscopical examination of freeze-substituted cells would support the hypothesis that the LPS polysaccharide chains extend perpendicularly from the surface of the cell (Lam et al., 1992). Thus, the charge originating from phosphate groups in the core/lipid A may be 'shielded' by Opolysaccharide chains, which would be stabilized with divalent cations in the case of B-band LPS (Peterson et al., 1985) and the charge at the environmental interface of the bacterium lowered (estimated to extend 31-36 nm from the outer-membrane bilayer in P. aeruginosa; Lam et al., 1992). If this were the case, the decrease in the charge originating from the core/lipid A in cells possessing only A-band LPS would be less than that for cells possessing only B-band LPS, due to the shorter length of A-band 
LPS. This was found to be the case, and the fact that complete removal of $\mathrm{A}$-and $\mathrm{B}$-band $\mathrm{O}$-side-chains resulted in maximal binding to the positively charged groups would support the hypothesis that the major chargedetermining species reside in the LPS core/lipid A. These findings are supported by a previous study in which the retention of rough and smooth Salmonella typhimurium on an anion-exchange resin was examined (Hermansson et al., 1982). These authors found that loss of the O-sidechain significantly increased the binding to the charged column.

Many authors have attempted to apply colloid models such as the Derjaguin, Landau, Verwey and Overbeek (DLVO) theory to explain the adhesion of bacteria to surfaces (Busscher et al., 1984; Gilbert et al., 1993; Marshall et al., 1971; Rutter \& Vincent, 1980; Van Loosdrecht $e$ t al., 1990). In this model, if contact pressure and temperature are constant and the molecular composition of the surface remains constant, then it is valid to assume that there is an inverse correlation between bacterial surface free energy and hydrophobicity (Busscher et al., 1984). In addition, as the bacterial cell surface and most substrata in natural environments possess net negative charges, one of the most obvious parameters influencing adhesion would seem to be surface electronegativity (Rutter \& Vincent, 1980). In recent years, it has thus become evident that correlations exist between adhesion to surfaces and non-specific surface characteristics such as surface charge and hydrophobicity (Gilbert et al., 1991; Gordon \& Millero, 1984; Hermansson et al., 1982; James et al., 1985; Rainey, 1991; Van Loosdrecht et al., 1987a, b).

In the present study, the surface characteristics primarily responsible for adhesion were dependent upon the physicochemical characteristics of the substratum. When glass was used as a hydrophilic, negatively charged surface, the greatest adhesion was seen for the strains possessing B-band LPS (PAO1 and dps89). These strains were the most hydrophilic and had the lowest cell surface charge. Strains AK1401 and $\operatorname{rd} 7513\left(\mathrm{~A}^{+} \mathrm{B}^{-}\right.$and $\mathrm{A}^{-} \mathrm{B}^{-}$, respectively), which were more hydrophobic and had higher negative surface charges, adhered to glass less well. These data would imply that the surface charge was the main mediator of adhesion to a hydrophilic surface, the decreased surface electronegativity accounting for the increased adhesion to the negatively charged surface. For hydrophobic polystyrene, however, higher adhesion was seen for the more hydrophobic strains (AK1401, $A^{+} B^{-}$; $\left.\operatorname{rd} 7513, A^{-} B^{-}\right)$and the results obtained exactly mirrored the HIC data $\left(\mathrm{A}^{+} \mathrm{B}^{-}>\mathrm{A}^{-} \mathrm{B}^{-}>\mathrm{A}^{+} \mathrm{B}^{+}>\mathrm{A}^{-} \mathrm{B}^{+}\right)$.

These findings are supported by Van Loosdrecht $e t$ al. (1987b), who determined the hydrophobicities, electrophoretic mobilities and adhesion characteristics of 23 bacterial strains and concluded that for bacteria with hydrophobic cell surfaces, hydrophobicity was the primary mediator of adhesion to a negatively charged, hydrophobic surface, whereas for cells possessing more hydrophilic surfaces, surface charge played an increasingly important role. Gilbert et al. (1991) also concluded that for Escherichia coli there was a good correlation between adhesion to glass and electronegativity, but not hydrophobicity.

Paul \& Jeffrey (1985) found evidence for separate adhesion mechanisms for hydrophilic and hydrophobic surfaces in Vibrio proteolytica and proposed that proteins were involved in the latter. They found that various proteolytic enzymes and surfactants decreased cell surface hydrophobicity and inhibited $(>97 \%)$ the attachment of $V$. proteolytica to hydrophobic polystyrene, but had no effect on adhesion to hydrophilic glass. Conversely, Van Haeke et al. (1990) quantified the surface hydrophobicities of $15 P$. aeruginosa strains and examined the adhesion to electropolished stainless steel. In contrast to our present study, they found a correlation only between hydrophobicity (as determined by contact angle measurement and bacterial adhesion to hydrocarbons) and adhesion, although the authors failed to investigate the LPS characteristics of the strains used. No correlation was found between surface charge and adhesion. Miller \& Ahearn (1987) also found greater adhesion of $P$. aeruginosa to hydrophobic contact lenses when compared to hydrophilic contact lenses, although no attempt was made to characterize the bacterial cell surface hydrophobicity or charge.

In $P$. aeruginosa, the relative amounts of $\mathrm{A}$ - and B-band LPS produced on the cell surface appear to be under environmental control. In the present study we have shown that both surface charge and cell surface hydrophobicity are profoundly influenced by the expression of these two LPS types which ultimately help control their adhesion to hydrophobic and hydrophilic surfaces. In the wild-type organism, the hydrophobic A-band LPS would presumably be shielded by the longer, and more hydrophilic, B-band LPS. Conformational changes in the Bband structure (i.e. dynamic folding), however, could expose the more hydrophobic A-band LPS. If these conformational changes were prompted by attachment to a surface, it may aid in the firm attachment of the bacterium. In addition, the distribution of A-band and Bband LPS upon the cell surface is, at present, unclear and it is not known if the LPS types are randomly distributed or if distinct domains, enriched in A-band or B-band LPS, exist. If such domains were to exist, they would offer the possibility of distinct areas on the cell surface which would favour attachment to either hydrophilic or hydrophobic surfaces. Conversely, if the distribution of the different LPS types was random and disperse, it may be that attachment to a surface would prompt migration of a particular LPS type to the point of attachment in such a way as to strengthen the attachment. Attachment to surfaces with subsequent colonization and growth as a biofilm offers distinct survival advantages when compared to planktonic growth. These advantages may be due to accumulation of nutrients at the hydrodynamic boundary layer (Fletcher, 1992), modulation of the physicochemical microenvironment (Davies et al., 1993; Davies \& Geesey, $1995)$ and increased resistance to antimicrobial agents (Anwar et al., 1990; Gilbert et al., 1990; Nickel et al., 1985). We propose, therefore, that changes in surface characteristics which favour adhesion to surfaces, 
mediated by alterations in the LPS composition and/or configuration of the outer membrane, may constitute an important adaptation and survival strategy for $P$. aeruginosa and, possibly, other Gram-negative bacteria.

\section{ACKNOWLEDGEMENTS}

This work was supported by a grant (to T. J.B.) from the Medical Research Council of Canada. We would like to thank Dianne Moyles and Anuradha Saxena for expert technical assistance and Dr Jagath Kadurugamuwa for helpful discussions. We are grateful to Dr Joseph Lam for the strains and monoclonal antibodies.

\section{REFERENCES}

Absolom, D. R. (1988). The role of hydrophobicity in infection: bacterial adhesion and phagocytic ingestion. Can J Microbiol 34, 287-298.

Anwar, H. M., Dasgupta, M. K. \& Costerton, J. W. (1990). Testing and susceptibility of bacteria in biofilms to antimicrobial agents. Antimicrob Agents Chemother 34, 2043-2046.

Arsenault, T. L., Hughes, D. W., Maclean, D. B., Szarek, W. A., Kropinski, A. M. B. \& Lam, J. S. (1991). Structure studies on the polysaccharide portion of 'A band' lipopolysaccharide from a mutant (AK1401) of Pseudomonas aeruginosa strain PAO1. Can J Chem 69, 1273-1280.

Berry, D. \& Kropinski, A. M. (1986). Effect of lipopolysaccharide mutations and temperature on plasmid transformation efficiency in Pseudomonas aeruginosa. Can J Microbiol 32, 436-438.

Brause, B. D. (1989). Infected orthopedic prostheses. In Infection Associated with Indwelling Medical Devices. Edited by A. L. Bisno \& F. A. Waldvogel. Washington, DC: American Society for Microbiology.

Busscher, H. J., Weerkamp, A. H., van der Mei, H. L., van Pelt, A. J. W., DeJong, H. P. \& Arends, J. (1984). Measurement of surfacefree energy of bacterial cell surfaces and its relevance for adhesion. Appl Environ Microbiol 48, 980-983.

Christensen, B. E. \& Characklis, W. G. (1990). Physical and chemical properties of biofilms. In Biofilms, pp. 93-130. Edited by W. G. Characklis \& K. C. Marshall. New York: John Wiley.

Costerton, J. W., Cheng, K. J., Geesey, G. G., Ladd, P. I., Nickel, J. C., Dasgupta, M. \& Marrie, T. J. (1987). Bacterial biofilms in nature and disease. Annu Rev Microbiol 41, 435-464.

Dagostino, L., Goodman, A. E. \& Marshall, K. C. (1991). Physiological responses induced in bacteria adhering to surfaces. Biofouling 4, 113-119.

Davies, D. G. \& Geesey, G. G. (1995). Regulation of the alginate biosynthesis gene algC in Pseudomonas aeruginosa during biofilm development in continuous culture. Appl Environ Microbiol 61, 860-867.

Davies, D. G., Chakrabarty, A. M. \& Geesey, G. G. (1993). Exopolysaccharide production in biofilms: substratum activation of alginate gene expression by Pseudomonas aeruginosa. Appl Environ Microbiol 59, 1181-1186.

Dazzo, F. B. (1984). Bacterial adhesion to plant root surfaces. In Microbial Adhesion and Aggregation. Edited by K. C. Marshall. Berlin: Springer-Verlag.

Fletcher, M. (1992). Bacterial metabolism in biofilms. In Biofilms: Science and Technology. Edited by C. F. Melo, T. R. Bott, M. Fletcher \& B. Capdeville. Dordrecht: Kluwer Academic Publishers.

Gilbert, P., Collier, P. J. \& Brown, M. R. W. (1990). Influence of growth rate and susceptibility to antimicrobial agents : biofilms, cell cycle, dormancy, and stringent response. Antimicrob Agents Chemother 34, 1865-1868.

Gilbert, P., Evans, D. J., Evans, E., Duguid, I. G. \& Brown, M. R. W. (1991). Surface characteristics and the adhesion of Eschericbia coli and Stapbylococcus epidermidis. J Appl Bacteriol 71, 72-77.

Gilbert, P., Evans, D. J. E. \& Brown, M. R. W. (1993). Formation and dispersal of bacterial biofilms in vivo and in situ. J Appl Bacteriol (Supp) 74, 67S-78S.

Giwercman, B., Jensen, T. E., Hoiby, N., Kharazmi, A. \& Costerton, J. W. (1991). Induction of $\beta$-lactamase production in Pseudomonas aeruginosa biofilm. Antimicrob Agents Chemother 35, 1008-1010.

Gordon, A. S. \& Millero, F. J. (1984). Electrolyte effects on attachment of an estuarine bacterium. Appl Environ Microbiol 47, 495-499.

Hancock, R. E. W. \& Crey, A. M. (1979). Outer membrane of Pseudomonas aeruginosa: heat and 2-mercaptoethanol-modifiable proteins. J Bacteriol 140, 902-910.

Hancock, R. E. W., Mutharia, L. M., Chan, L., Darveau, R. P., Speert, D. P. \& Pier, G. B. (1983). Pseudomonas aeruginosa isolates from patients with cystic fibrosis: a class of serum-sensitive, nontypable strains deficient in lipopolysaccharide $\mathrm{O}$ side chains. Infect Immun 42, 170-177.

Hermansson, M., Kjelleberg, S., Korhonen, T. K. \& Stenstrom, T. A. (1982). Hydrophobic and electrostatic characterization of surface structures of bacteria and its relationship to adhesion to an air-water interface. Arch Microbiol 131, 308-312.

Herson, D. S., McGonigle, B., Payer, M. A. \& Baker, K. H. (1987). Attachment as a factor in the protection of Enterobacter cloacae from chlorination. Appl Environ Microbiol 53, 1178-1180.

Hitchcock, P. \& Brown, T. M. (1983). Microheterogeneity among Salmonella lipopolysaccharide chemotypes in silver stained polyacrylamide. J Bacteriol 154, 269-277.

James, D. W., Suslow, T. V. \& Steinback, K. E. (1985). Relationship between rapid firm adhesion and long-term colonization of roots by bacteria. Appl Environ Microbiol 50, 392-397.

Kadurugamuwa, J. L., Lam, J. S. \& Beveridge, T. J. (1993). Interaction of gentamicin with the A band and B band lipopolysaccharides of Pseudomonas aeruginosa and its possible lethal effect. Antimicrob Agents Chemother 37, 715-721.

Kihlstrom, E. \& Magnusson, K. E. (1980). Association with HeLa cells of LPS mutants of Salmonella typbimurium and Salmonella minnesota in relation to their physico-chemical surface properties. Cell Biophys 2, 177-189.

Kinniment, S. L. \& Wimpenny, J. W. T. (1992). Measurement of the distribution of adenylate concentrations and adenylate charge across Pseudomonas aeruginosa biofilms. Appl Environ Microbiol 58, 1629-1635.

Knirel, Y. A., Vinogradov, E. V., Kocharova, N. A., Paramonov, N. A., Kochetkov, N. K., Dmitriev, B. A., Stanislavsky, E. S. \& Lanyi, B. (1988). The structure of O-specific polysaccharide and serological classification of Pseudomonas aeruginosa. Acta Microbiol Hung 35, 3-24.

Lam, J. S., Graham, L. L., Lightfoot, J., Dasgupta, T. \& Beveridge, T. J. (1992). Ultrastructural examination of the lipopolysaccharides of Pseudomonas aeruginosa strains and their isogenic rough mutants by freeze substitution. J Bacteriol 174, 7159-7167.

Lam, M. Y. C., McGroarty, E. J., Kropinski, A. M., MacDonald, L. A., Pedersen, S. S., Hoiby, N. \& Lam, J. S. (1989). Occurrence of a common lipopolysaccharide antigen in standard and clinical strains of Pseudomonas aeruginosa. J Clin Microbiol 27, 962-967.

Lightfoot, J. \& Lam, J. S. (1991). Molecular cloning of genes involved with expression of A-band lipopolysaccharide, an anti- 
genically conserved form, in Pseudomonas aeruginosa. J Bacteriol 173, 5624-5630.

Lock, M. A. (1993). Attached microbial communities in rivers. In Aquatic Microbiology, pp. 113-138. Edited by T. E. Ford. Boston: Blackwell.

Lugtenberg, B., Meijers, J., Peters, R., van der Hoek, P. \& van Alphen, L. (1975). Electrophoretic resolution of the "major outer membrane protein' of Escherichia coli $\mathrm{K} 12$ into four major bands. FEBS Lett 58, 254-258.

Magnusson, K. E. \& Johansson, G. (1977). Probing the surface of Salmonella typhimurium and Salmonella minnesota $\mathrm{SR}$ and $\mathrm{R}$ bacteria by aqueous biphasic partitioning in systems containing hydrophobic and charged polymers. FEMS Microbiol Lett 2, 225-228.

Marshall, K. C., Stout, R. \& Mitchell, R. (1971). Selective sorption of bacteria from seawater. Can J Microbiol 17, 1413-1416.

Miller, M. J. \& Ahearn, D. G. (1987). Adherence of Pseudomonas aeruginosa to hydrophilic contact lenses and other substrata. J Clin Microbiol 25, 1392-1397.

Nickel, J. C., Heaton, J., Morales, A. \& Costerton, J. W. (1985). Tobramycin resistance of Pseudomonas aeruginosa cells growing as a biofilm on urinary catheter material. Antimicrob Agents Chemother 27, 619-624.

Ormerod, L. D. \& Smith, R. E. (1986). Contact lens-associated microbial keratitis. Arch Opbthalmol 104, 79-83.

Palomar, J., Leranoz, A. M. \& Vinas, M. (1995). Serratia marcescens adherence: the effect of O-antigen presence. Microbios 81, 107-113.

Paul, J. H. \& Jeffrey, W. H. (1985). Evidence for separate adhesion mechanisms for hydrophilic and hydrophobic surfaces in Vibrio proteolytica. Appl Environ Microbiol 50, 431-437.

Pendersen, K. (1981). Electrostatic interaction chromatography, a method for assaying the relative surface charge of bacteria. FEMS Microbiol Lett 12, 365-367.

Peterson, A. A., Hancock, R. E. W. \& McGroarty, E. J. (1985). Binding of polycationic antibiotics and polyamines to lipopolysaccharides of Pseudomonas aeruginosa. J Bacteriol 164, 1256-1261.

Rainey, P. B. (1991). Phenotypic variation of Pseudomonas putida and Pseudomonas tolaasii affects attachment to Agaricus bisporus mycelium. J Gen Microbiol 137, 2769-2779.

Rivera, M. \& McGroarty, E. J. (1989). Analysis of a common antigen lipopolysaccharide from Pseudomonas aeruginosa. J Bacteriol 171, 2244-2248.

Rivera, M., Bryan, L. E., Hancock, R. E. W. \& McGroarty, E. J. (1988). Heterogeneity of lipopolysaccharides from Pseudomonas aeruginosa: analysis of lipopolysaccharide chain length. $J$ Bacteriol $170,512-521$.
Rutter, P. R. \& Vincent, B. (1980). The adhesion of microorganisms to surfaces: physicochemical aspects. In Microbial Adhesion to Surfaces. Edited by C. W. Berkeley, J. M. Lynch, J. Melling, P. R. Rutter \& B. Vincent. Chichester: Ellis Horwood.

Smyth, C. J., Jonsson, P., Olsson, E., Soderlind, O., Rosengren, J., Hjerten, S. \& Wadstrom, T. (1978). Differences in hydrophobic surface characteristics of porcine enteropathogenic Escherichia coli with and without $\mathrm{K} 88$ antigen as revealed by hydrophobic interaction chromatography. Infect Immun 22, 462-472.

Stenstrom, T. A. (1989). Bacterial hydrophobicity, an overall parameter for the measurement of adhesion potential to soil particles. Appl Environ Microbiol 55, 142-147.

Svanborg-Eden, C., Hagberg, L., Hull, R., Hull, S., Magnusson, K. E. \& Ohman, L. (1987). Bacterial virulence versus host resistance in the urinary tract of mice. Infect Immun 55, 1224-1232.

Tsai, C. \& Frasch, C. E. (1982). A sensitive silver stain for detecting LPS in polyacrylamide gels. Anal Biochem 119, 115-119.

Van Haeke, E., Remon, J. P., Moors, M., Raes, F., DeRudder, D. \& Van Peteghem, A. (1990). Kinetics of Pseudomonas aeruginosa adhesion to 304 and 316-L stainless steel: role of cell surface hydrophobicity. Appl Environ Microbiol 56, 788-795.

Van Loosdrecht, M. C. M., Lyklema, J., Norde, W., Schraa, G. \& Zehnder, A. J. B. (1987a). The role of bacterial cell wall hydrophobicity in adhesion. Appl Environ Microbiol 53, 1893-1897.

Van Loosdrecht, M. C. M., Lyklema, J., Norde, W., Schraa, G. \& Zehnder, A. J. B. (1987b). Electrophoretic mobility and hydrophobicity as a measure to predict the initial steps in bacterial adhesion. Appl Environ Microbiol 53, 1898-1901.

Van Loosdrecht, M. C. M., Lyklema, J., Norde, W. \& Zehnder, A. J. B. (1990). Influence of interfaces on microbial activity. Microbiol Rev 54, 75-87.

Walan, A. \& Kihlstrom, E. (1988). Surface charge and hydrophobicity of Campylobacter jejuni strains in relation to adhesion to epithelial HT-29 cells. APMIS 96, 1089-1096.

Warren, J. W. (1987). Catheter associated urinary tract infections. Infect Dis Clin North Am 1, 823-854.

Wilkinson, S. G. (1983). Composition and structure of lipopolysaccharides from Pseudomonas aeruginosa. Rev Infect Dis 5, S941-S949.

Williams, P., Lambert, P. A., Haigh, C. G. \& Brown, M. R. W. (1986). The influence of the $\mathrm{O}$ and $\mathrm{K}$ antigens of Klebsiella aerogenes on surface hydrophobicity and susceptibility to phagocytosis and antimicrobial agents. J Med Microbiol 21, 125-132.

Received 1 August 1995; revised 2 October 1995; accepted 9 October 1995. 